\title{
South Africa's Shrinking Sovereignty: Economic Crises, Ecological Damage, Sub-Imperialism and Social Resistances
}

\author{
T. Ngwane \\ University of Johannesburg, Johannesburg, South African Republic \\ P. Bond \\ University of the Western Cape, Capetown, South African Republic
}

\begin{abstract}
The development of contemporary South Africa political economy occurred within the context of a global capitalist order characterized by increasingly unequal political and economic relations between and within countries. Before liberation in 1994, many people across the world actively supported the struggle against apartheid, with South Africa's neighbouring states paying the highest price.

The 'sovereignty' of the apartheid state was challenged by three processes: first, economic, cultural and sporting sanctions called for by Nelson Mandela's African National Congress and other liberation movements, which from the 1960s-80s were increasingly effective in forcing change; second, solidaristic foreign governments including Sweden's and the USSR's provided material support to overthrowing the Pretoria Regime; and third, military defeat in Angola and the liberation of neighbouring Mozambique (1975), Zimbabwe (1980) and Namibia (1990) signalled the inevitability of change. But that state nevertheless maintained sufficient strength - e.g. defaulting on foreign debt and imposing exchange controls in 1985 - to ensure a transition to democracy that was largely determined by local forces.

Since 1994, the shrinkage of sovereignty means the foreign influences of global capitalism amplify local socioeconomic contradictions in a manner destructive to the vast majority of citizens. This is evident when considering economic, ecological, geopolitical and societal considerations.

Key words: commons, economy, environment, neoliberalism, protest, South Africa, Africa, decolonisation, sovereignty, sub-imperialism

For citation: Ngwane, T. \& Bond, P. (2020). South Africa's Shrinking Sovereignty: Economic Crises, Ecological Damage, Sub-Imperialism and Social Resistances. Vestnik RUDN. International Relations, 20 (1), 67-83. DOI: 10.22363/2313-0660-2020-20-1-67-83
\end{abstract}

Научная статья

\section{Ограничение суверенитета Южной Африки: экономические кризисы, экологический урон, субимпериализм и социальное сопротивление}

\author{
Т. Нгване
}

Университет Йоханнесбурга, Йоханнесбург, Южно-Африканская Республика

\section{П. Бонд}

Университет Западной Капской провинции, Кейптаун, Южно-Африканская Республика

Развитие современной экономико-политической системы Южной Африки происходило в контексте глобального капитализма, характеризующегося неравными политическими и экономическими отношениями между

(C) Ngwane T., Bond P., 2020 
странами и внутри стран. До освобождения ЮАР от апартеида в 1994 г. многие люди во всем мире активно поддерживали борьбу против этого режима, причем соседние государства Южной Африки заплатили за это самую высокую цену.

«Суверенитет» режима апартеида был поставлен под сомнение тремя процессами: во-первых, экономическими, культурными и спортивными санкциями, к которым призывал АНК Нельсона Манделы, и другие освободительные движения которые с 1960-х по 1980-е гг. становились все более эффективными и требовали перемен; во-вторых, солидарностью со стороны иностранных правительств, включая Швецию и СССР, которые оказали материальную поддержку для свержения режима Претории; в-третьих, военным поражением ЮАР в Анголе и провозглашением независимости соседних Мозамбика (1975), Зимбабве (1980) и Намибии (1990), сигнализировавшими о неизбежности перемен. Но режим апартеида тем не менее сохранял силу - например, посредством объявления дефолта по внешнему долгу и введением валютного контроля в 1985 г. — для последующего перехода к демократии, который в значительной степени определялся местными силами.

С 1994 г. ограничение суверенитета означает, что иностранные влияния глобального капитализма усиливают локальные социально-экономические противоречия таким образом, что это губительно для подавляющего большинства граждан. Это очевидно при рассмотрении экономических, экологических, геополитических и социальных соображений, представленных в статье.

Ключевые слова: общественное достояние, экономика, окружающая среда, неолиберализм, протест, Южная Африка, Африка, деколонизация, суверенитет, субимпериализм

Для цитирования: Ngwane T., Bond P. South Africa's Shrinking Sovereignty: Economic Crises, Ecological Damage, Sub-Imperialism and Social Resistances // Вестник Российского университета дружбы народов. Серия: Международные отношения. 2020. T. 20. № 1. С. 67-83. DOI: 10.22363/2313-0660-2020-20-1-67-83

South Africa is considered the most unequal society in the world (using the Gini income coefficient, at 0.79 before state transfers), and Johannesburg is the world's most unequal major city (according to the Palma ratio, at 13.4) ${ }^{1}$. A massive battle to correct the racial component of inequality - the colonial and apartheid legacy - was partly won in 1994, but economic injustices worsened thereafter. In a global neocolonial context of adverse North - South power relations, South Africans are being robbed of key elements of national sovereignty; many important political-economic and environmental decisions are taken without their participation and without significant benefit to themselves. And although South Africa is usually considered the second or third largest economy in Africa (behind Nigeria and sometimes Egypt), and although from 1930 - 1980 the economy attained a high degree of industrialization (manufacturing reached a quarter of GDP), it deindustrialized

1 Fiscal policy and redistribution in an unequal society // World Bank Group. November 2014. URL: https://www.worldbank.org/en/country/southafrica/publica tion/south-africa-economic-update-fiscal-policy-redistri bution-unequal-society (accessed: 10.02.2020); Income inequality ranking of the world's major cities // Euromonitor. October 31, 2017. URL: https://blog.euromonitor.com/ income-inequality-ranking-worlds-major-cities/ (accessed: 10.02.2020). rapidly during the 1990s. Its growing role as a 'sub-imperial' albeit neoliberal power leaves the financial benefits of regional domination to escape the country. A vast share of profits drawn from the continent have been exported via Johannesburg, along with illicit financial flows and depleted natural resources, leaving both Africa and South Africa ever poorer.

When Nelson Mandela was released from prison in 1990, there was hope not only for the country but for the continent, given that his African National Congress (ANC) cadres were mainly exiled in Zambia, Tanzania and Zimbabwe, there witnessing the 1980s era of structural adjustment. However, the results have been disappointing largely because the South African political elite committed the country to a neoliberal capitalist path that underdeveloped large swathes of the economy and society. South Africans from all walks of life will concede that the country is in crisis and will point to the regular electricity failures ('loadshedding'), record levels of unemployment (near $40 \%$ ), and poverty (around $65 \%$ under $3 \mathrm{USD} /$ day, corruption in the private and state sector ('state capture'), extremely serious gender-based violence and abuse of children, the resurgence of racism and xenophobia, and other morbid symptoms of a society and economy which cry out for change. 
The pages below sum up lengthier arguments that feed into the "Alternative Report on Africa" (AROA), an ongoing project that the Senegalese NGO ENDA and the Pan-African intellectual network Codesria are advancing against the Washington Consensus. Using the framework of 'sovereignty', we argue that sector by sector, the neoliberal developmental path chosen by the South African elite has failed. There is a need for a very different approach, grounded in local realities and eco-social needs. We strongly identify with what AROA seeks, continentally: a new interpretation of Africa in order to bring out endogenous visions and struggles capable of improving the well-being of the populations.

To do so, we draw upon traditions of protest by numerous communities, trade unions, youth and gender activists and social movements that contest injustice. The desire for both national sovereignty and popular sovereignty — including by women, workers, youth, environmentalists and all oppressed peoples, separately and together in unity - is extremely powerful in South Africa, and in many cases has been directed against the way globalized economic relations have limited national and popular sovereignty.

With South Africa's rising level of social conflict as background, we take as a foundational argument the following concern expressed by AROA: "In capitalist societies, the dominant social bloc always conceives of national sovereignty as an instrument for promoting its class interests; namely, capitalist exploitation of domestic work and, at the same time, the consolidation of its positions in the world system. Today, in the context of a liberalized globalized system dominated by the financialized monopolies of the 'triad' (United States, Europe, Japan) and the BRICS (Brazil, Russia, India, China, South Africa), national sovereignty is the instrument that allows the ruling classes to maintain their competitive positions within the system" [Alternative Report on Africa 2019: 4].

In that regard, given that "the exercise of sovereignty cannot be achieved without a radical strategy of disconnection from the globalized capitalist system," as Samir Amin told a 2017 AROA gathering in Dakar, we accept its challenge: "The aim is to identify the invariants and incipient changes at work in Africa, at the dawn of the 21 st century. This analytical identification should lead to proposals of scenarios from which strategies can be defined and proposed at national, sub-regional and continental levels" [Alternative Report on Africa 2019: 1, 4]. Our conclusion aims to do just that, drawing on two major currents of thinking: Amin's [1990] 'delinking' and a new set of ecosocialist-feminist, anti-racist, anti-imperial experiments in 'commoning,' of which the campaign to acquire free treatment for AIDS was most spectacular because it turned intellectual property over medicines into a public good, saving millions of lives, by rejecting the World Trade Organization's Trade Related Intellectual Property System and winning an exemption (i.e. delinking).

One reason this was such a difficult struggle for people living with HIV, was the Pretoria government's 2000-2004 unwillingness to demand and win sovereignty to treat its citizens. Hence this article begins by addressing the sometimes parochial approach of political leadership and leading intellectuals, who surrendered sovereignty of their very mindsets before, during and after South Africa's transition to democracy in 1994. The second section then shows how this unfortunate outcome reflected a logic of economic concessions in the context of capitalist crises and financialization, and how the results for ordinary people's welfare were terribly unsatisfactory.

The next set of arguments are sectoral. The super-exploitative character of the extractive industries and failure to carry out land reform, which in turn are related to the failure to establish food sovereignty, are explored in the third section, along with a critique of fossilreliant energy during worsening climate crisis. The fourth addresses some of the controversies associated with new technologies, highlighting social resistance strategies and tactics. The section also surveys threats in the military, state security and foreign policy spheres where concerns continue to grow about Pretoria's repressive tendencies and surveillance capacities at home, as well as in the wider region, adding to the crisis of working-class xenophobia. The 
conclusion draws out central lessons from the report in order to offer a different scenario, based on the last quarter-century of uneven social resistance: to be sure, an unlikely scenario for a second stage of liberation, beyond the democratic achievements of 1994, and into the eco-socialist, feminist, anti-imperial politics of the 'commons'... unlikely but surely necessary.

\section{Political-intellectual Sovereignty, from Apartheid to Neoliberalism}

Today's South African political elites - the ANC's leading cadres - are a product of the anti-apartheid struggle and thus of the 20th century's left-leaning, state-centric developmental aspirations. When political liberation was attained in 1994, the global conjuncture was unfavourable, leading to the ANC's moderation under Mandela's leadership, and later abandonment of pro-working class and pronational sovereignty perspectives. The demise of both the USSR's patronage and Europe's social democratic traditions, and the rise of economic neoliberalism precipitated the capitulation, away from the ANC's 1955 Freedom Charter and 1994 Reconstruction and Development Programme (RDP), towards a 1996 home-grown structural adjustment programme.

The reasons were two-fold: internal and external. The class composition of ANC leadership and many local allies within the 'Mass Democratic Movement' (a network that, from 1983-1994, fatally undermined apartheid within South Africa) reflected limitations of the political theories and strategies associated with the 'National Democratic Revolution'. This was the 'two-stage' approach to first eradicating official racism and then - at some future stage, far away - addressing economic injustice. But externally, too, the unfavourable changes in the global political context - especially the USSR's collapse - not only disoriented the ANC elites, but also led them to adopt an apparent pragmatism that was ideologically consistent with the logics and dominant interests of global capital. The weaknesses of the ANC leadership's approach to political economy left a debilitating loss of direction and of intellectual sovereignty that the country has suffered for more than a quarter century. Ultimately, the elites allowed themselves to play the role of a sidekick to imperialism, termed sub-imperialism.

The adoption of neoliberal macro-economic policies that gradually undermined the majority's living conditions prevailed under the presidencies of Mandela (1994-1999), Thabo Mbeki (1999-2008), Kgalema Motlanthe (2008-2009 as caretaker for eight months), Jacob Zuma (2009-2018) and Cyril Ramaphosa (2018 present). What is extraordinary in South Africa, though, is that this condition is maintained within what is often, rhetorically, quite radical African nationalist rule, turbulent though it has been. (Two presidents - Mbeki in 2008 and Zuma in 2018 - were removed in palace coups.)

Intellectuals also lost sovereignty in the post-apartheid era, with the uniquely South African theoretical critiques largely fading into oblivion as many important scholars whose work was fused with anti-apartheid insights then joined the post-1994 government. Taking a longer view of economic and social relations, the various South African traditions of radical political economy were always infused with concern about race, geography and also, increasingly, gender and environment. All came together in studies of superexploitative capitallabor relations that underpinned apartheid. For example, Ben Magubane [2001] periodized South African racism's functionality to superexploitative capitalist circuits during various epochs. During the 1800s, "the expanding frontier of 'settler capitalism' saw the recrudescence of the worst form of racism. The old social relations of usurious and commercial capitalism, with its conquistadors and slaves, were replaced by the dominion of industrial capital, with its plantation and wage slaves" [Magubane 2001: 6].

Racial restrictions were initially considered by political economists primarily as power relationships. As an early Trotskyist, Moshe Noah Averbach, explained, migrant labor would "prevent the formation of a stable, hereditary urban proletariat which would become used to the traditional methods of organization and struggle - trade union and political — of the city working classes" [Averbach 1936: 131]. But 
the Chamber of Mines also recorded how the 'cheap labor' system was crucial to their profitability (in official testimony to a 1944 government commission): "The mines are able to obtain unskilled labor at a rate less than ordinarily paid in industry... otherwise the subsidiary means of subsistence would disappear and the laborer would tend to become a permanent resident upon the Witwatersrand, with increased requirements" (cited in: [Wolpe 1972: 434]).

The central concern of radical political economists remained race/class at the point of production. Although more and more workers began living permanently in cities near manufacturing jobs, there was still a large supply of migrant labor. From 1948 through the 1970s, $3.5 \mathrm{mln}$ people were forcibly removed onto the reserves, which could simply not handle the environmental demands placed on them. The migrant 'tribal natives' did not, when they were young, live under a system that required companies to pay their parents enough to cover school fees, or pay taxes for government schools to teach workers' children. When sick or disabled, those workers were often shipped back to their rural homes until ready to work again. When the worker was ready to retire, the employer typically left him a pittance, not a pension that allowed the elderly to survive in dignity. From youth through to illness to old age, the subsidy covering child-rearing, recuperation and old age was provided by rural African women. Ann-Marie Wolpe [Kuhn, Wolpe 1978] added a vital feminist angle to the debate, given how much the reproduction of male labor in the Bantustans raised the profit rate.

An upsurge of anti-apartheid protest resumed when the Durban labor movement began at the ports in 1973, followed by the Soweto student uprising of 1976, and with the economic slowdown beginning around 1974, political economists' attention turned from aspects of apartheid-capitalist stability and control, to instability and crisis. The broader theoretical discourse about race and class in South Africa seemed to peak in the 1970s, and with rigorous detailed probing underway in the 1980s in the context of the search for specificity, research into the nature of the mode of production tailed off markedly.

As to the changing dynamics between capitalists and state elites, not only did the mid1980s conjuncture split whites between the English running business in Johannesburg and Afrikaners running the government in Pretoria, but the latter group themselves divided into bitter-end 'verkramptes' who soon lost their earlier hegemony, and neoliberal 'verligtes' led by FW de Klerk. He gained the presidency in 1989 and six months later freed Mandela and unbanned the ANC, SACP and other much smaller liberation movements. That political shift was due to overlapping pressures and contradictions then bubbling up, including widespread township protest and workplace revolts, declining profits in part due to the overaccumulated capital that stood exposed after the gold price collapsed in 1980, growing political delegitimation thanks to ANC sanctions campaigning, and the economy's overexposure to world financial power. International financiers suddenly turned hostile to Pretoria in August 1985 after a new round of repression by PW Botha's government, cancelling lines of credit; their hands were forced by solidarity activists promoting banking sanctions.

By the late 1980s, the larger questions were again placed on the agenda, because it was a time when South Africa's capitalist class demanded, for the first time, an end to formal apartheid. The reasons for this are closely related to economic stagnation and financial crisis, but what was disconcerting was how dramatically this shook many political economists who, earlier, so profoundly rejected the liberal thesis that apartheid and capitalism were incompatible.

Ben Fine and Zav Rustomjee cautioned: "The relationship between abstract theory and empirical application is not unique to the study of South Africa. But the virulent form taken by its racism within the bounds of a predominantly capitalist economy has cast considerable doubt on the simple expedient of examining South Africa's development in terms of hypotheses derived from ready-made analytical frameworks" [Fine, Rustomjee 1996: 21]. Their own approach was institutionalist, by identifying the nexus of a 
Minerals-Energy Complex around which accumulation, state, labor relations and other economic phenomena could be understood. A decade later, Fine [2008] also addressed the postapartheid political economic nexus in terms of financialization, as "macroeconomic policy has been designed to manage the capacity of the South African conglomerates to disinvest".

In contrast, leading ANC intellectuals such as Thabo Mbeki [2004] and Joel Netshitenzhe - justified the neoliberal economic policies they inherited and amplified, arguing that South Africa was suffering from 'two economies', and as for those left out, "of central and strategic importance is the fact that they are structurally disconnected from our country's 'first world economy"'.

Yet there remain many structural connections still reminiscent of older labor migration systems, as SA Communist Party youth leader (and later, from 2019, deputy finance minister) David Masondo [2007] observed: "A combination of unreconstructed vulgar Marxism and modernization theory have provided conceptual basis for contemporary neoliberalism, which is dressed up as the 'first economy' drawing in the 'second economy' to a successful market process." Moreover, warned Masondo, "the CST and its National Democratic Revolution strategy is also used by some in the ANC to justify the current neoliberal incorporation of the emerging black bourgeoisie into the structure of capital accumulation" [Masondo 2007]. The subsequent period of Zuma's rule, 2009-2018, led many to conclude that South Africa' suffered from 'neopatrimonialism', since major corruption scandals (involving the Gupta and Watson families) reduced South Africa's leadership to a caricature.

At no point in the post-1994 era were the fundamentals of capital accumulation based on super-exploitative extractive industries, featuring multinational corporations and parasitical class formation, ever genuinely questioned. What we have seen in this first quarter-century of ANC rule is a lack of genuine political and intellectual sovereignty, in part due to the pragmatism of South Africa's leaders, including its scholars. To understand that pragmatism requires a review of
South Africa's shrinking economic sovereignty, including the ability of the state to reverse the wrongs of apartheid.

\section{Economic Sovereignty Wanes during Capitalist Crises}

In 1933, John Maynard Keynes' essay in the Yale Review, 'Economic self-sufficiency,' included this mandate: "I sympathize with those who would minimize, rather than with those who would maximize economic entanglement among nations. Ideas, knowledge, science, hospitality, travel - these are the things which should of their nature be international. But let goods be homespun whenever it is reasonably and conveniently possible and, above all, let finance be primarily national" [Keynes 1933].

Ignoring this wisdom, the ANC liberalized the economy since the mid-1990s [Bond 2014]. Economic sovereignty was lost when the postindependence governing elite capitulated to capitalist interests and adopted the logic of the Washington Consensus. The apartheid state was already moving towards neoliberal policies when it was defeated and taken over by the forces of national liberation. The main dynamic of political developments in the transition from apartheid to democracy occurred in the sphere of capital accumulation and its attendant crises. Indeed, it was capital which abandoned the apartheid regime in favour of a pro-capitalist neoliberal democratic regime because the problems of low profitability and capital accumulation could not be solved within the old racist framework, in part because of the volatile political conditions created by the anti-apartheid struggle.

In other words, the incoming ANC leaders agreed to and were willing handmaidens of global neoliberal interests; for example, they accepted an IMF loan in 1993 before the transition to democracy, they relaxed the 1985 exchange controls and allowed big capital to list companies in European and North American stock exchanges, they reduced company tax dramatically, they acceded to the World Trade Organization on disadvantageous terms, and they fell under the influence of New York's credit 
ratings agencies: Standard \& Poors, Fitch and Moody's. Even before they took power in 1994, the ANC elite facilitated the country's shrinking economic sovereignty.

The consequences for society was the abandonment of pro-poor ambitions in favour of the World Bank-authored Growth, Employment and Redistribution programme in 1996, exactly two years after Mandela had taken power based on RDP promises. Despite expanding what are essentially 'tokenistic' social grants of $25-30$ USD/month to more than eleven million children as well as $100 \mathrm{USD} /$ month grants to another few million pensioners, the dominant policy in South Africa has been 'corporate welfare'. Big business, whether 'white monopoly capital' or emanating from Black Economic Empowerment (BEE) schemes, benefited most from postapartheid policies. The BEE strategy to nurture a small black bourgeoisie whetted the selfenrichment appetites of the black elite, and served to provide cover for big capital and win legitimacy for capitalism.

The adoption of financial and monetary systems that serve capitalist interests contributed significantly to shrinking economic sovereignty. Management of South Africa's economy has been characterized by supervisory laxity, deregulation, corporate corruption and excessive financial speculation. The new government abolished the Finrand dual exchange-rate designed to penalize offshoring; corporate listing requirements were removed; and building societies' domination of the home mortgage bond lending disappeared. Protections against usury rate escalation were compromised through allowing major exemptions, thus permitting excessive interest states especially on small loans. Regulatory oversight in this era was scant, with repeated scandals associated with illicit financial flows, currency manipulation and other corporate malfeasance. Many international accounting firms and consultancies - even KPMG, Bain, Deloitte, PwC, McKinsey and Hogan Lovells - were implicated in corruption associated with the notorious South African firms Eskom, Transnet, Steinhoff, Tongaat, VBS Bank and African Bank and others. During the 2010s, South Africa's capitalist class was repeatedly ranked by $\mathrm{PwC}$ as the world's most prone to corporate criminality [Bond, Malikane 2019].

Many of these policy changes in the fiscal, monetary and financial-regulatory spheres were the outcome of international pressures. Domestic policy was overpowered in these areas, thus compromising sovereignty. The working class and the poor, who bear the brunt of the economic consequences of this disempowerment, pay dearly and thus remain locked in South Africa's inherited class, race and gender inequality. Specific examples of international pressure include the compulsion for the new democratic government to repay 25 billion USD apartheid; the tutor-pupil relationship with the Bretton Woods Institutions; and South Africa's ascension to the World Trade Organization leading to lowering its tariffs on manufactured goods. These observations point to South Africa's negative insertion in the global capitalist order, in turn suggesting the desirability of Amin's strategy of delinking from the most adverse international relations [Bond 2014].

For example, the Jubilee 2000 campaign asked the new government to refuse repayment of the apartheid regime's 25 billion USD in foreign 'Odious Debt' passed to the democracy in 1994, a request repeatedly refused by Mandela and Mbeki. That debt skyrocketed to 180 billion USD within 25 years, because its repayment was compounded by the outflow of profit, dividends and interest especially after 2001. Multinational corporations and South African firms that had relocated abroad drained the foreign exchange reserves. The interest rate that Pretoria paid on foreign state loans was, by 2020 , fourth highest in the world among the 45 countries issuing 10-year bonds (tailing only Turkey, Argentina and Pakistan - and higher even than Venezuela). Other morbid symptoms of financialization included high levels of corporate, state and consumer debt in local credit markets.

Another case of international influences in the financial markets is South Africa's main stock market, the Johannesburg Stock Exchange, which reached dizzying heights by early 2018 : the highest market capitalization/GDP ratio for a country in modern history (more than 
350 percent). In 2018, the market's 20 percent crash was caused mainly by the Chinese government's restrictions on Tencent video game marketing, which reflected the outsized investment in that firm by a South African newspaper firm, Naspers, which had become the continent's richest company thanks to its lucky bet of $35 \mathrm{mln}$ USD to buy a third of Tencent in 2001 (by 2018 this investment reached a value in excess of 150 billion USD). In September 2019, Naspers moved the profit inflows from Tencent to a new Amsterdam company, Prosus, which will dramatically diminish the ratio of local to international dividend payments, further weakening South Africa's economic sovereignty.

Fig. 1 shows South Africa's relatively high level of dividend inflows relative to outflows, which locates it strongly within a (subimperial) range from 15-80\%, albeit below the range above $100 \%$ which boosts capital accumulation in the imperial economies. Defenders of the globalization process point to the 2002-2015 commodity super-cycle, when platinum, coal, iron ore and gold prices helped drive the rise in Gross National Income. Still, the peak years 2003-2008 - witnessed real growth in the 2.5-5.5\% range, far below the level needed to address the crises of unemployment, poverty and inequality (Fig. 2). Note that in measuring natural capital decline in the form of mineral depletion above, the Bank does not include platinum or diamonds due to measurement difficulties, thus overestimating South Africa's ANS.

\section{Extreme Resource Extraction, Land Mismanagement, Hunger and Energy Crisis}

The super-exploitative character of South African political ecology is apparent in several areas: extractive industries, land abuse, hunger and fossil-fuel dependency. Together, these provide another approach to sovereignty, in relation to natural resources. The International Monetary Fund's ${ }^{2}$ accounting of public assets

\footnotetext{
${ }^{2}$ Fiscal Monitor: Managing Public Wealth // International Monetary Fund. Washington, DC, 2018. URL: https:/www.imf.org/ /media/Files/Publications/fiscalmonitor/2018/October/pdf/fm1802.ashx?la=en (08.02.2020).
}

ranks the South African state within the world's leading countries as a result of the vast stock of non-renewable mineral resources (Fig. 3). However, untenable national resource depletion and maldistribution are combined with rising ecological concerns about climate change, given that the South African economy ranks behind only Kazakhstan and the Czech Republic in $\mathrm{CO}_{2}-$ equivalent emissions per unit of per capita GDP (among countries with more than ten million people). South Africa's extractive industries are highly destructive of the environment in a variety of other ways, including destruction of freshwater resources, world-record levels of nitrous oxide air emissions and other particulate matter, ocean pollution, threats to the fauna and flora and reduced biodiversity.

The extraction of South Africa's nonrenewable minerals is also a major factor in the country's wealth shrinkage, another reflection of capital's super-exploitation of natural economy. National wealth is now calculated by economists to include the changes in an economy's produced capital, human capital and natural capital ${ }^{3}$. The 'Adjusted Net Savings' (ANS) measure is designed to reform Gross National Income (GNI) in order to estimate 'genuine savings', namely, the depreciation of physical capital, damage caused by pollution and the depletion of natural resources (viewed as debits from GNI), as well as educational investment (a credit added to GNI). The ANS is a crude sign of progress, as development economists grow more concerned with sustainability. The price the earth pays as a result of its exploitation by capitalist extractive industry is increasingly evident, and although we oppose any marketization of this process through natural capital accounting (such as emissions trading or biodiversity offsets), the approximate measurement of the cost to countries like South Africa is part of acknowledging the 'ecological debt' associated with the Anthropocene, especially the Capitalocene that has driven environmental destruction in the name of profit.

${ }^{3}$ Little Green Data Book // World Bank. Washington, DC: World Bank Group, 2017. URL: http://documents.worldbank.org/curated/en/239271500275 879803/pdf/117480-PUB-Date-6-29-2017-PUBLIC.pdf (accessed: 12.01.2020). 


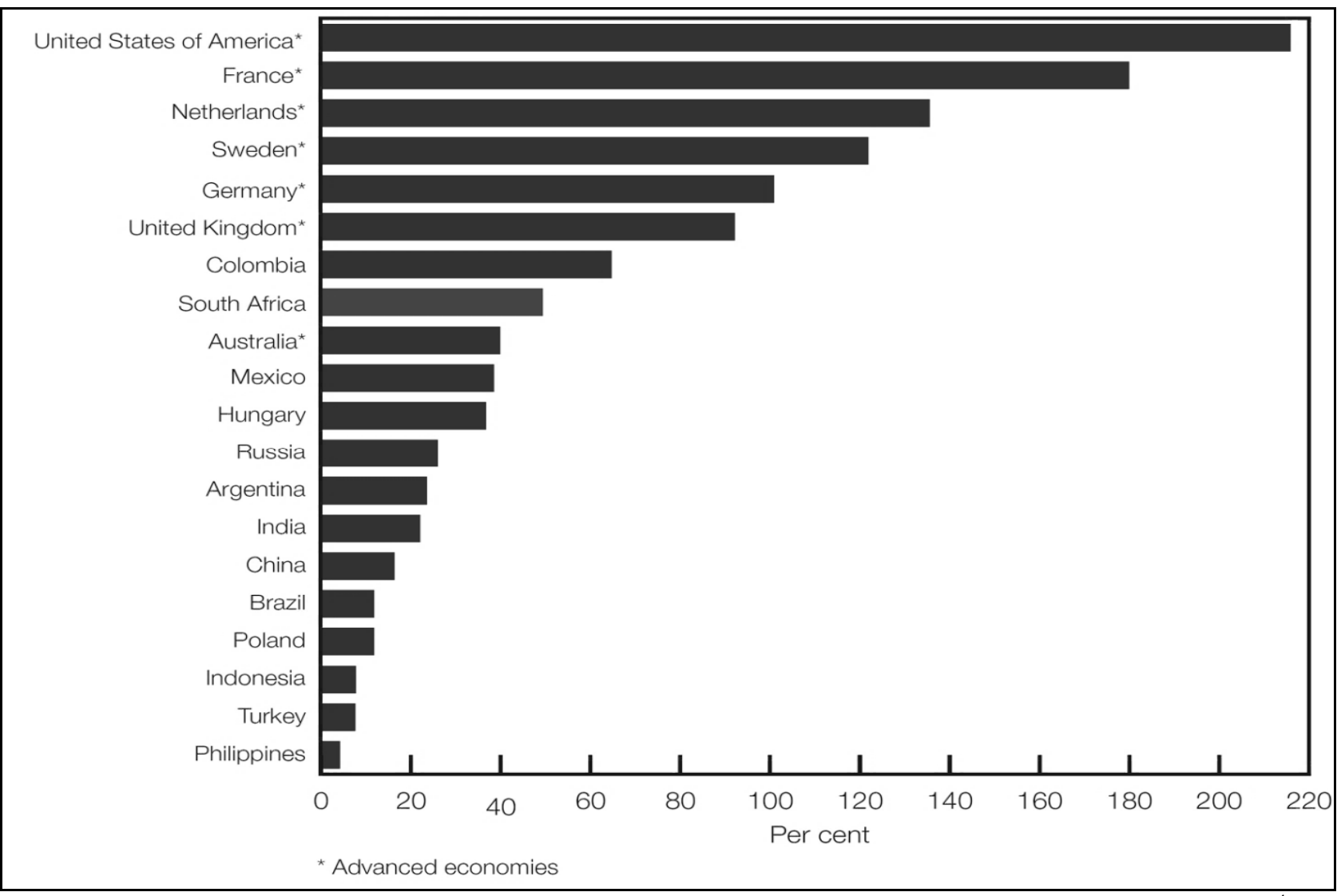

Fig. 1. Average dividend receipts as a percentage of dividend payments for selected countries, 2015-2017

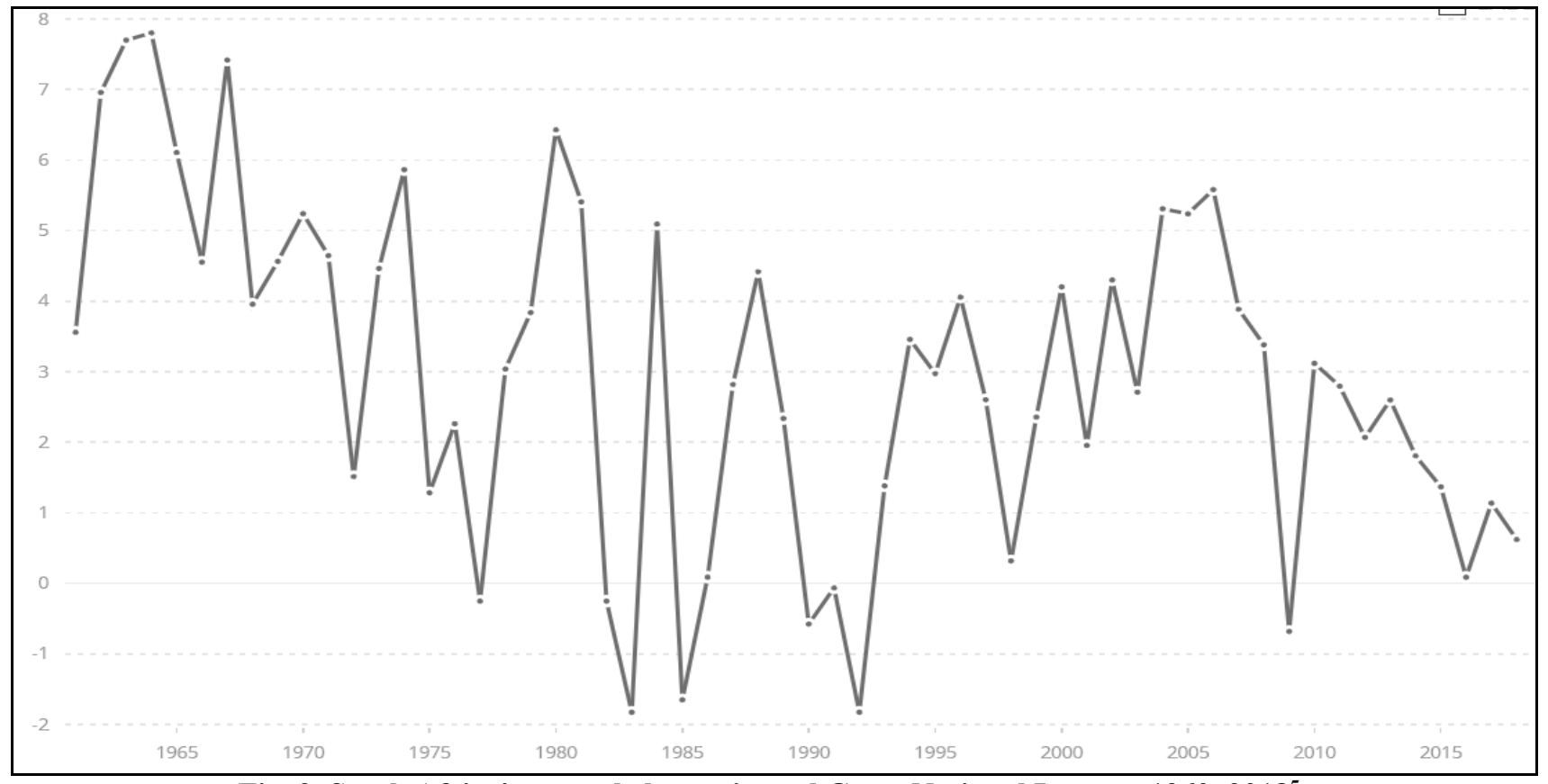

Fig. 2. South Africa's annual change in real Gross National Income, 1960-2018

\footnotetext{
${ }^{4}$ Quarterly Bulletin // South African Reserve Bank. December 2019. Pretoria.

${ }^{5}$ Life expectancy at birth // World Bank. Washington, DC: World Bank Group, 2020. URL: https://data.worldbank.org/indicator/SP.DYN.LE00.IN?locations=ZA-1W (accessed: 02.02.2020).
} 


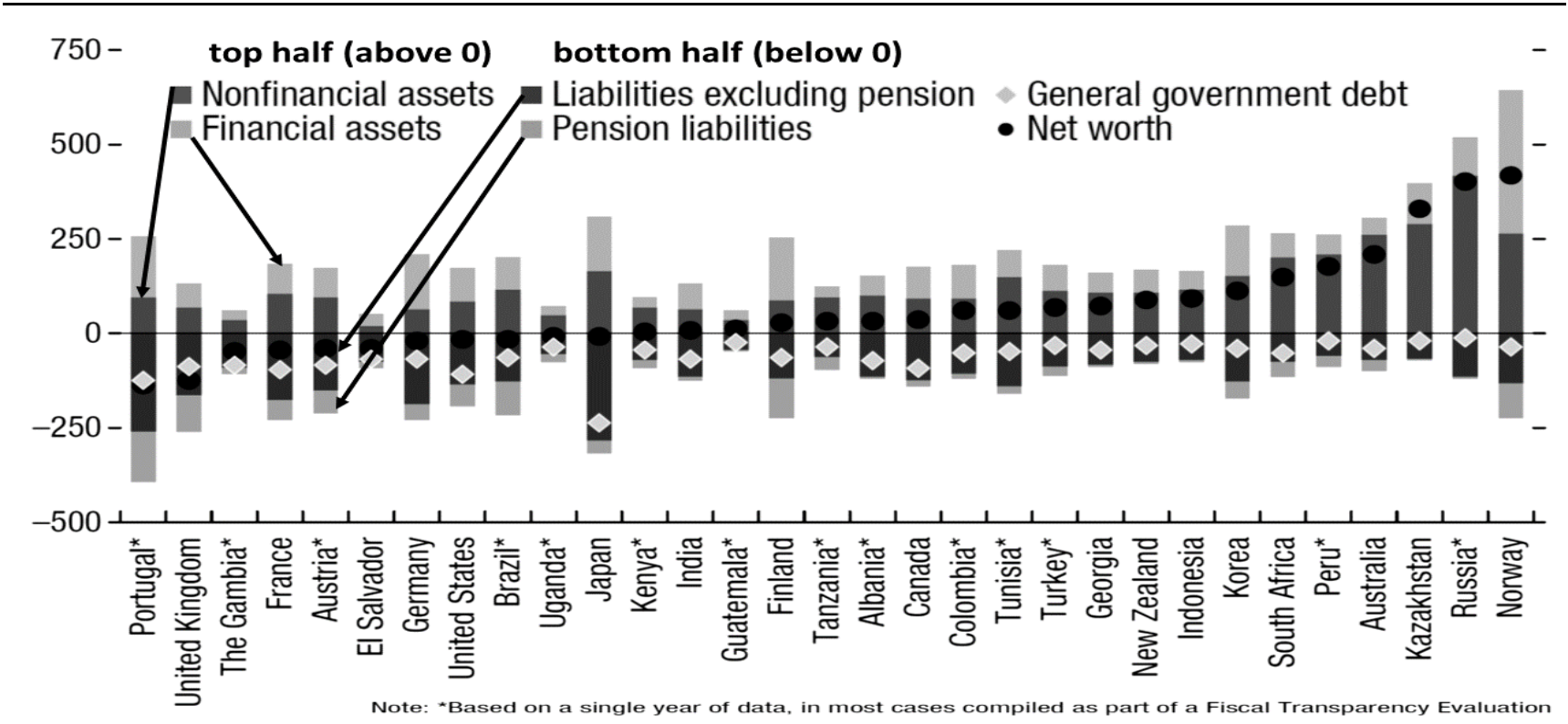

Fig. 3. Resource wealth of selected states: public sector balance sheets (\% of GDP) ${ }^{6}$

\begin{tabular}{|c|c|c|c|c|c|c|c|}
\hline \multirow[t]{3}{*}{$\begin{array}{l}\text { Population (millions) } \quad 55.0 \text { Land area }(1,000 \mathrm{sq} . \mathrm{km}) \quad 1 \\
\end{array}$} & \multicolumn{3}{|c|}{1,213 GDP ( $\$$ billions) 314.6} & & \multirow[b]{2}{*}{$\begin{array}{c}\text { Country } \\
\text { data }\end{array}$} & \multirow{2}{*}{$\begin{array}{l}\text { Sub- } \\
\text { Saharan } \\
\text { Africa } \\
\text { group }\end{array}$} & \multirow{2}{*}{$\begin{array}{l}\text { Upper } \\
\text { middle- } \\
\text { income } \\
\text { group }\end{array}$} \\
\hline & \multirow[b]{2}{*}{$\begin{array}{c}\text { Country } \\
\text { data }\end{array}$} & \multirow{2}{*}{$\begin{array}{l}\text { Sub- } \\
\text { Saharan } \\
\text { Africa } \\
\text { group }\end{array}$} & \multirow{2}{*}{$\begin{array}{l}\text { Upper } \\
\text { middle- } \\
\text { income } \\
\text { group }\end{array}$} & & & & \\
\hline & & & & \multicolumn{4}{|l|}{$\begin{array}{l}\text { Water and sanitation } \\
\text { Internal freshwater resource }\end{array}$} \\
\hline \multirow{3}{*}{$\begin{array}{l}\text { GNI per capita, World Bank Atlas method (\$) } \\
\text { Adjusted net national income per capita (\$) } \\
\text { Urban population (\% of total) }\end{array}$} & \multirow{3}{*}{$\begin{array}{r}6,080 \\
4,671 \\
64.8\end{array}$} & \multirow{3}{*}{$\begin{array}{r}1,631 \\
1,239 \\
37.7\end{array}$} & \multirow{3}{*}{$\begin{array}{r}8,263 \\
6,302 \\
64.1 \\
\end{array}$} & Total freshwater withdrawal (\% of internal resources) & 34.6 & 3.2 & 6.3 \\
\hline & & & & Agriculture (\% of total freshwater withdrawal) & 63 & 81 & 68 \\
\hline & & & & Access to improved water source (\% of total population) & 93 & 68 & 95 \\
\hline \multicolumn{4}{|l|}{ Agriculture } & Rural (\% of rural population) & 81 & 56 & 91 \\
\hline \multirow{3}{*}{$\begin{array}{l}\text { Agricultural land (\% land area) } \\
\text { Agricultural irrigated land (\% of total agricultural land) } \\
\text { Agricultural productivity, value added per worker ( } 2010 \$ \text { ) } \\
\text { Cereal yield (kg per hectare) }\end{array}$} & \multirow{3}{*}{$\begin{array}{r}80 \\
1.7 \\
9,451 \\
4,894\end{array}$} & 42 & 35 & Urban (\% of urban population) & 100 & 87 & 97 \\
\hline & & 1219 & 2208 & Access to improved sanitation (\% of total population) & 66 & 30 & 80 \\
\hline & & 1,452 & 4,104 & Rural (\% of rural population) & 61 & 23 & 67 \\
\hline \multicolumn{4}{|l|}{ Forests and biodiversity } & Urban (\% of urba & & 40 & 87 \\
\hline $\begin{array}{l}\text { Forest area (\% land area) } \\
\text { Deforestation (avg. annual \%, 2000-15) }\end{array}$ & $\begin{array}{l}7.6 \\
0.0\end{array}$ & $\begin{array}{r}25.7 \\
0.5\end{array}$ & $\begin{array}{r}34.9 \\
0.0\end{array}$ & \multicolumn{4}{|l|}{ Environment and health } \\
\hline Terrestrial protected areas (\% of total land area) & 8.9 & 15.3 & 15.2 & (e (ue/cu, m) & 30 & 36 & 42 \\
\hline Threatened species, mammals & 26 & 918 & 1,056 & (PE/(cu. III) & 50 & 30 & $4 L$ \\
\hline Threatened species, birds & 46 & 876 & 1,511 & sceeding WHO guideline level) & 100 & 99 & 95 \\
\hline Threatened species, fish & 107 & 2,023 & 2,315 & Acute resp. infection prevalence (\% of children under five) & ." & 5 & . \\
\hline Threatened species, higher plants & 116 & 3,740 & 6,808 & Diarrhea prevalence (\% of children under five) & .. & 14 & 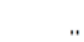 \\
\hline \multicolumn{4}{|l|}{ Oceans } & Under-five mortanity rate (per 1,000 live births) & 41 & 83 & 19 \\
\hline \multirow{3}{*}{$\begin{array}{l}\text { Total fisheries production (thousand metric tons) } \\
\text { Capture fisheries growth (avg. annual \%, 2000-15) } \\
\text { Aquaculture growth (avg. annual \%, 2000-15) }\end{array}$} & \multirow{3}{*}{$\begin{array}{r}578 \\
-1.0 \\
5.6 \\
13.4\end{array}$} & 7,416 & 103,240 & & & & \\
\hline & & 1.8 & -0.5 & National accounting aggregates-savings, depleti & tion and $\mathrm{d}$ & degradatio & \\
\hline & & 17.0 & 5.3 & Gross savings (\% of GNI) & 16.8 & 14.4 & 36.6 \\
\hline Marine protected areas (\% of territorial waters) & 13.4 & $\begin{array}{r}6.1 \\
17980\end{array}$ & $\begin{array}{r}9.9 \\
48880\end{array}$ & Consumption of fixed capital (\% of GNI) & 14.3 & 13.8 & 18.0 \\
\hline $\begin{array}{l}\text { Coral reef area }(\mathrm{sq} . \mathrm{km}) \\
\text { Mangroves area }(\mathrm{sq} . \mathrm{km})\end{array}$ & 30.5 & $\begin{array}{l}17,980 \\
28,061\end{array}$ & $\begin{array}{l}48,880 \\
50,774\end{array}$ & Education expenditure (\% of GNI) & 6.0 & 3.3 & 3.0 \\
\hline IVIallgroves died (sq. KIII) & & & & oy denletion (\% of GNI) & 0.0 & 0.5 & 0.0 \\
\hline Energy and emissions & & & & & 0.1 & & \\
\hline Energy use per capita (kg oil equivalent) & 2,715 & 701 & 2,192 & Mineral depletion (\% of GNI) & 1.1 & 0.9 & 0.4 \\
\hline Energy from biomass products and waste (\% of total) & 10.5 & 57.4 & 7.3 & Net forest depletion (\% of GNI) & 0.0 & 2.3 & 0.0 \\
\hline Electric power consumption per capita (kWh) & 4,229 & 497 & 3,495 & $\mathrm{CO}$, damage (\% of GNI) & 4.6 & 1.6 & 2.6 \\
\hline Electricity generated using fossil fuel (\% of total) & 93.1 & 64.3 & 71.1 & Air pollution damage (\% of GNI) & 0.4 & 1.2 & 0.3 \\
\hline Electricity generated by hydropower (\% of total) & $\begin{array}{l}0.4 \\
8.8\end{array}$ & $\begin{array}{r}21.2 \\
0.8\end{array}$ & 21.0 & Adiusted net savinoss (\% of GNI) & 15 & -39 & 172 \\
\hline $\mathrm{CO}_{2}$ emissions per capita (metric tons) & 8.8 & 0.8 & 6.6 & Adjustea net savings (\% of GivI) & 1.5 & -3.9 & 11.2 \\
\hline
\end{tabular}

Fig. 4. Breakdown of South Africa's per capita wealth depletion, 2014 (in USD) ${ }^{7}$

6 Fiscal Monitor: Managing Public Wealth // International Monetary Fund. Washington, DC, 2018. URL: https://www.imf.org/ /media/Files/Publications/fiscal-monitor/2018/October/pdf/fm1802.ashx?la=en (08.02.2020).

7 Little Green Data Book // World Bank. Washington, DC: World Bank Group, 2017. URL: http://documents.worldbank.org/curated/en/239271500275879803/pdf/117480-PUB-Date-6-29-2017-PUBLIC.pdf (accessed: 12.01.2020). 
How does this change on an annual basis, reflecting wealth depletion associated with extractive industries? As reproduced in Fig. 4, the five major categories in which annual output should be adjusted downwards are: 1) consumption of fixed capital in the form of wear-andtear depreciation (14.3\% of South Africa's нтинента он2 damage (4.6\%), 3) mineral depletion $(1.1 \%), 4)$ energy depletion $(0.7 \%)$, and 5) air pollution $(0.4 \%)^{8}$. The (controversial) upward adjustment of education spending is 6 percent of GNI even though it could easily be argued that South African schooling locks in structural disadvantage [Spaull 2013]. The result is a total ANS of $1.5 \%$ of GNI, not the $16.8 \%$ considered to be gross annual savings.

The snapshot capital accounts provided by the World Bank ${ }^{9}$ allows further contemplation of the destruction of South Africa's natural economy (Fig. 4). These accounts are not yet sufficiently strong in data consistency to compare across time periods, so as to assess the depletion process. But they do allow more breakdown of what is pre-existing "nature" (albeit after several centuries of settler-colonial interventions) and what society must make special efforts to preserve. There are, for instance, nearly 300 "threatened species," including 116 higher plants, 107 fish, 46 birds and 26 mammals. The natural economy of the human lung is also threatened, with $100 \%$ of the population having PM2.5 particle exposure higher than World Health Organisation guideline levels; under-5 mortality rates are more than twice as high as the average peer (upper middleincome) country. South Africa's freshwater hydrological natural economy suffers massive withdrawal, ten times as much as do other African economies and more than five times the rate of upper middle-income peer economies. And in every category of energy aside from hydropower, South African capitalism uses far

\footnotetext{
${ }^{8}$ Little Green Data Book // World Bank. Washington, DC: World Bank Group, 2017. URL: http://documents.worldbank.org/curated/en/239271500275 879803/pdf/117480-PUB-Date-6-29-2017-PUBLIC.pdf (accessed: 12.01.2020).

${ }^{9}$ Ibid.
}

more than do other African and upper middleincome economies.

The most destruction comes in the form of $\mathrm{CO}_{2}$-equivalent emissions, which are eleven times higher for an 'average' South African (that mythical construct), than the 0.8 tons per average Sub-Saharan African. During the 2015-2019 period, the boomerang of eco-destruction from fossil fuel abuse became evident with several debilitating droughts, cyclones and floods attributed to greenhouse gas emissions. In Cape Town in 2017-2018, the city's 'Day Zero' supply constraint (to result in full retail disconnections) was nearly breached, while in 2019, Durban and surrounds suffered a 'rain bomb' of $150 \mathrm{~mm}$ in one day that killed 71 people. Malawi, Mozambique and Zimbabwe suffered two cyclones in March - April 2019 with at least a thousand people dying. Droughts in South Africa's farm belt, especially the Karoo, Eastern Cape and Northern Cape, have already caused widespread hunger.

There and everywhere, South Africa's food sovereignty is also threatened by massive agroindustrial profiteering, which artificially inflates prices and lowers quality. The sector is dominated by large commercial farmers including by a handful of corporate giants who drive the availability, price, quality, safety and nutritional value of food consumed by all South Africans. This monopoly is regularly abused; for example, major milling and baking producers have been found guilty of fixing the price of bread, wheat and maize through cartels. Competition Commission investigations also found that the dairy and fishing industries were guilty of price fixing. The high cost of basic food items has resulted in lowincome households suffering a higher inflation rate than the general population [Bond, Malikane 2019]. As a result of these tactics and general poverty, $11 \mathrm{mln}$ people are estimated to experience food insecurity, i.e., not knowing where their next meal is coming from [Bond, Galvin 2019]. As many as $1.5 \mathrm{mln}$ children under the age of 6 years have stunted growth due to chronic malnutrition. Food insecurity is characterized by geographical biases, is gendered, and 
is more prevalent among the black African population.

Likewise, the concept of energy sovereignty has proven elusive for the South African majority (all those without resources to establish their own solar system or diesel power generators). Since 2008, the country has faced regular power outages, called loadshedding. This is due both to the failure of ageing coal-fired power stations to keep up with the country's energy demands, and to design flaws in two new coal-fired mega-plants. The economy is paying dearly as a result of the stoppage of machines in the mines, smelters and other energy-reliant industries. The domestic, retail and service sectors are also hard hit.

The solution, according to many social movements and NGOs concerned about this issue, is for South Africa to stop producing energy through fossil fuels, and urgently move towards renewable sources. Due mainly to vested interests in the coal sector (Ramaphosa himself was a coal tycoon before returning to government in 2014), the government has been very slow despite the abundant sun and wind resources in the country. Instead, it has agreed to buy electricity from private 'independent power producers' (mainly European corporations) at high prices compared with coal. Trade unions in the sector argue that their jobs are threatened by the decentralization and privatization of energy generation, but unfortunately have not reached a critical mass of support in demanding a genuine Just Transition. With the climate crisis knocking on the door of humanity, South African elites seem least ready to do anything to alleviate nor prepare for it.

\section{The Knowledge Economy, State Surveillance, Sub-Imperial Power and Xenophobia}

The same incapacity to implement necessary radical changes is evident in the digital sphere, where leading South African government, business and academic leaders uncritically embrace the concept of the 'Fourth Industrial Revolution' (4IR) as espoused by the World Economic Forum's Karl Schwab. The evolution of new technologies is, from this point of view, presented as a positive, inevitable and unproblematic development. As a result, South Africans have not been well exposed to international concerns about distorted value systems through social-media manipulation, and Big Data's social engineering power (and political agenda). The South African debate centres around the impact of the 4IR and the extent to which society has sufficient information technology skills to reap the benefits of alleged human progress. This narrative undermines sovereignty insofar as it imposes the perspectives, projects and priorities of global capital - the Big Data firms especially in the country and across the continent.

Ordinary South Africans engaged in struggles against aspects of the 4IR suggest that this phenomenon is presented in a decontextualized and ahistorical fashion, ignoring the class, gender, race and geographical mediations now shaping technology. Examples of resistance include widespread opposition to Intellectual Property when it conflicts with access to cutting edge patented life-saving medicines (as discussed in the conclusion), surveillance systems associated with unjust forms of commodification (e.g. prepayment water meters and electronic highway tolls), and commodified education (resulting in a successful struggle for free tertiary education for working-class South Africans). A 'Right to Know' campaign has made the demand that cell phone access be considered a human right.

But with Africa still struggling to 'catch up' to the 'second industrial revolution', defined as electrification, let alone with the 'third industrial revolution', defined as digitization, it is apparent that 4IR is a mirage. South Africa has a very high rate of unemployment, especially among the youth, yet Ramaphosa waxes eloquent about labor-saving super technologies embodied in the 4IR, including 'smart cities' based on the Internet of Things. A more considered and critical approach to digitization and the knowledge economy would recognize technological developments as having all manner of biases, leading to even more unequal power relations.

One example is the way surveillance systems have been used by the South African 
state against activists. Military intelligence and other state policing bodies regularly spy on social movements and organizations engaged in protests and other oppositional activities. State repression ultimately finds expression in state violence. In 2012, this reality was clear to everyone during the Marikana Massacre where 34 miners were shot dead one afternoon for demanding a living wage. Of concern is the fact that South Africa is likely to experience more protests and strikes as the global capitalist crisis continues to bite with the country disadvantageously located as it is within the global economic order. A government lacking national sovereignty over its economic policies and thus without answers to a demanding and restless constituency is likely to respond with more repression.

To be sure, the apartheid-era war machine was tamed under the new democratic order, and the military was henceforth meant to be used only for peacekeeping purposes. The development of nuclear weapons was abandoned, and the weapons-producing capacity of the South African state focused on selling hardware rather than using it, and ensuring repressive regimes were rejected as purchasers. During the late 1990s, a notorious Arms Deal meant very expensive military equipment was purchased mainly from European suppliers, but it was characterized by greed, kickbacks and corruption. Without missing a beat, the new South African government sold lethal weapons to numerous repressive regimes, including the United States and Great Britain when they waged what was an illegal war in Iraq, largely to evict a former client authoritarian with control of vast oil resources.

African nations, and other peoples of the world, supported and sacrificed in the struggle to free South Africa from the shackles of apartheid. It was legitimately expected that when the continent's most powerful country is free, it would help and even lead the process of addressing Africa's massive set of challenges. As such, South Africa should be at the forefront of a Pan-African project that contests all features of neocolonialism. But consideration of South Africa's roles in Africa and the world reveals a worrying tendency by the Pretoria political elite and Johannesburg's most expansive capitalists to choose the path of neoliberalism rather than serving the values of Pan-Africanism. A careful analysis of South Africa's modus operandi brings to mind Brazilian dependency theorist Ruy Mauro Marini's definition of 'sub-imperialism': "It is not a question of passively accepting North American power (although the actual correlation of forces often leads to that result), but rather of collaborating actively with imperialist expansion, assuming in this expansion the position of a key nation" [Marini 1965: 22].

South Africa positioned itself in this manner on many occasions, including George W. Bush's 2003 state visit to South Africa where he called Mbeki his 'point man in Africa'. Even earlier, during the 1990s, the South African government adopted a pro-Western stance within the World Trade Organization. The neoliberal New Partnership for Africa's Development saw South Africa's Mbeki playing a leading role, warmly endorsed by the Bush regime as 'philosophically spot on'. South Africa is the sole African country within the G20, and in 2017 two of its cabinet ministers helped fashion the G20 'Compact with Africa' which aimed to subsidize both western and BRICS firms' investments.

Pretoria's role in BRICS has helped to legitimate repressive regimes in the other four partner countries, as the BRICS promote a kind of global governance reform (e.g. rising voting shares in the Bretton Woods Institutions) that both strengthens the Western pro-corporate grip and denudes poorer countries of influence (i.e. lower voting shares and ongoing structural adjustment, with no change in World Bank and IMF leadership). The BRICS' role in the United Nations Framework Convention on Climate Change has been especially invidious, in alliance with the West to prevent notions such as climate debt from being recognized. In these regards, Pretoria has chosen the path of playing sidekick to neoliberal BRICS and Western corporate interests, as opposed to serving Pan-Africanism in the struggle to attain sovereignty.

This positionality has also generated one of the most tragic contradictions: rampant xenophobia in the South African working class. 
Urbanization under conditions of capitalist crisis is full of tensions and contradictions. High levels of unemployment, poverty and inequality force many people to move from one place to another, sometimes crossing provincial or national borders, in order to find economic opportunities. Many immigrants end up in the cities because capitalist economic development concentrates power and resources in the urban space. They often do not get help or support but are defined as 'the Other' and rejected, especially when involved in competition over commerce (smallscale trading), employment and housing. The first major attack was in 2008 in Alexandra township, Johannesburg, and then spread throughout the country leaving 63 people dead. Another national outbreak occurred in 2010 following the World Cup. Sporadic but quite frequent outbreaks of xenophobia continued through 2019.

The state is also to blame because of its poor treatment of immigrants, including a hostile, inefficient and corrupt Department of Home Affairs which makes it difficult for people to get their papers in order. Progressive social movements have opposed xenophobia, organizing marches especially during periods of high tension and in the aftermath of attacks. Xenophobia undermines the struggle of workers and working-class communities by dividing their ranks in the struggle for a better life. Africa cannot enjoy sovereignty so long as Africans attack other Africans instead of uniting and standing together to solve common problems.

Anti-immigrant and often brutally xenophobic attitudes characterize South Africa and the rest of the world in the early $21 \mathrm{st}$ century. Yet the South African economy was built upon the labor of people from Africa, India, China, Europe and other parts of the world. In Africa, national borders drawn by the colonizers in 1884-1885 are now the basis for perpetual division. The anti-colonial struggle saw many instances of social solidarity among Africans as crystallized in Pan-Africanism, and it is in 'commoning' mutual aid that we find hope for a different future, based on not only political and economic sovereignty, but also human solidarity and ecological sustainability.

\section{Conclusion: Commoning for Change}

A different path of development was and is still possible for South Africa, but if only the dead-end of neoliberal policies is abandoned, and if delinking from the most destructive circuits of the world economy is pursued. The quest for African sovereignty requires waging another liberation struggle - a second decolonization as it were - whereby the myriad forms of social resistance found in various African countries must come together at local, national, regional and continental level. In addition to delinking from imperialism and rejecting sub-imperial power, South Africa's eco-socialist, feminist, anti-imperialist, anti-xenophobic tendencies of the movement for change can unite behind a project of 'commoning', that is, sharing the resources of the country and continent through 'bottom up' collective action that places the ecologically-sound satisfaction of human needs above the quest for private profit. The aim is to eradicate all forms of exploitation and oppression.

There are disputes, naturally, regarding how to tap into - and even measure - such activism. One indicator, relying upon mainstream media mentions of dissent, is a U.S. Pentagon-funded database (the 'Minerva Project') which suggests rising levels of protest from the early 2010s. The numeric peak was in September 2019 when both gender-based violence and xenophobia raged across South Africa, generating substantial resistance, as shown in Fig. 5.

These include, as noted above, daily battles over the conditions of labor's production and social reproduction. The most notorious was the August 2012 Marikana Massacre, which catalysed waves of worker anger that led to a firestorm of wildcat strikes (e.g. in the Western Cape's vineyards resulting in a doubling in the daily wage). If South African workers provide the best long-term antidote to the trends discussed above, even ANC leaders could not entirely suppress the energies of a working class often judged the world's most militant ${ }^{10}$.

10 The Global Competitiveness Report 2017-2018 // World Economic Forum. Davos, 2017. URL: http://www3. weforum.org/docs/GCR2017-2018/05FullReport/The GlobalCompetitivenessReport2017\%E2\%80\%932018.pdf (accessed: 03.02.2020). 


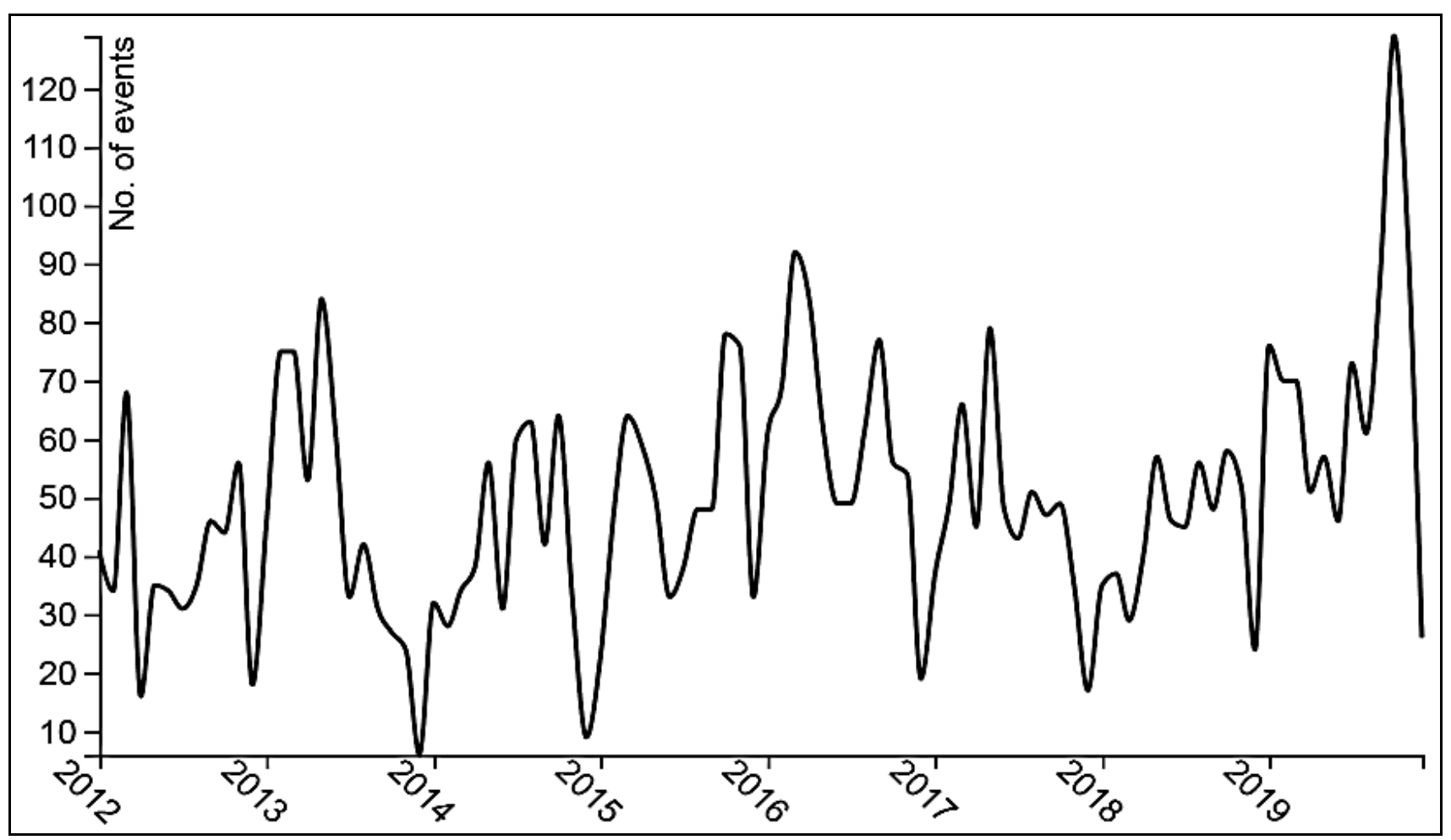

Fig. 5. Major protests in South Africa, 2012-2019 (monthly tally)

Source: Armed Conflict Location and Event Data (ACLED) Project. Brighton: University of Sussex, 2020. URL:

https://www.acleddata.com/dashboard (accessed: 16.01.2020).

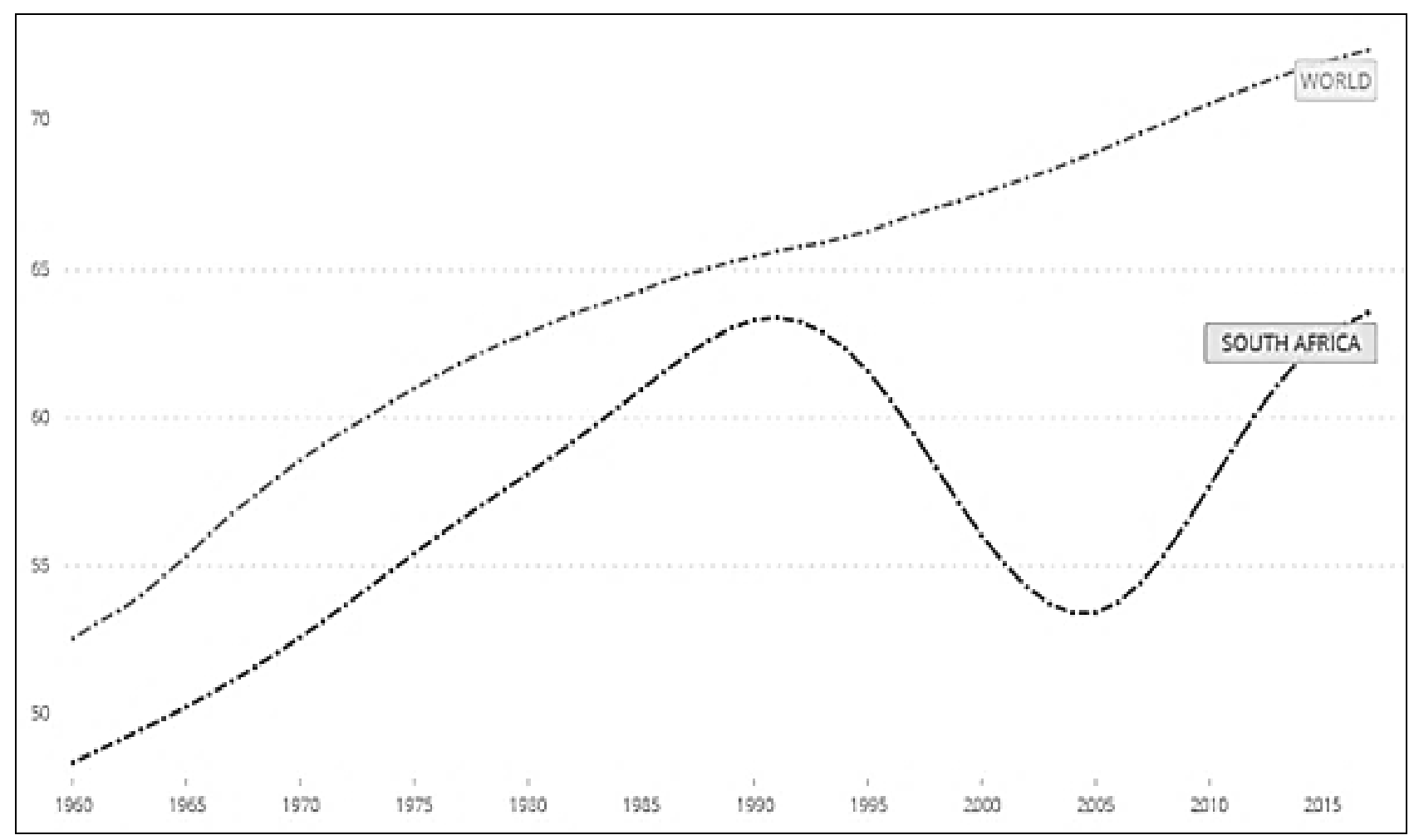

Fig. 6. South African and global life expectancy, 1960-201711

11 Life expectancy at birth // World Bank. Washington, DC: World Bank Group, 2020. URL: https://data.worldbank.org/indicator/SP.DYN.LE00.IN?locations=ZA-1W (accessed: 02.02.2020).

THEMATIC DOSSIER: Decolonization, Neocolonialism and Recolonization... 
Naturally, labor activists loyal to the ANC created divisions in major trade unions, leading to a 2013-2014 split of the largest federation into two, just as government imposed a new requirement that strikes first require a ballot, along with a subsidized sub-minimum wage for youth workers.

Also expressing disaffection - and suffering sometimes extreme repression - were radical social movements and prolific community protesters [Ngwane 2019]. In an earlier era of late 1990s dissent, these 'service delivery protests' won a major concession: a Free Basic Services policy providing minimal supplies of water and electricity (at least 25 liters/person/day and $50 \mathrm{kWh} /$ household/month). More recently, the most important commoning victories include the free tertiary education provided to $90 \%$ of university and technicalcollege students following their 2015-2017 national uprisings. The victory also included the 'in-sourcing' of low-paid workers, back into university employ.

But without question, South Africa's most successful commoning strategy was the early2000s acquisition of Anti-Retroviral medicines to combat AIDS. These are today provided free by the state, having once been the purview of global capital. They are responsible for reversing the dramatic early-2000s decline in South Africa's life expectancy, as shown in Fig. 6.

Because hundreds of thousands of people died unnecessarily in the struggle to gain access to AIDS medicines, this example of commoning is most spectacular. The successful campaign reflected four features that any post-neoliberal project should embrace: decommodification (of drugs costing over 15.000 USD/year that are now free); destratification of access (now numbering over $5 \mathrm{mln}$ South Africans); delinking and deglobalisation of capital (generic medicine production facilities now exist in many African cities); and global solidarities against powerful multinational forces. By jumping scale, South Africa's Treatment Action Campaign confronted global Big Pharma, the South African and US governments, and the World Trade Organization. In 2004 prior to medicines access, life expectancy was 52 years, and by 2019 it rose to 64: an extraordinary post-neoliberal victory.

Commoning is also increasingly common as a mode of day-to-day resistance. Throughout the townships of South Africa, activists interested in guaranteeing access to water and electricity have been attempting to evolve what was already a popular survival tactic at the time of apartheid: reconnecting water and electricity illegally, once it was disconnected by state officials due to nonpayment; in Soweto alone, the share of illegal electricity connections had risen to $80 \%{ }^{12}$.

The most serious problem with informal commoning, is that once the water infrastructure is tapped by township plumbers (many working for a small fee), leaks are exacerbated and water quality is sometimes compromised. Likewise, as electricity lines are commoned using illegal connections, the capacity of the entire township system is stressed and the power supply regularly trips. Accidental electrocutions become more frequent as live wires criss-cross pedestrian pathways. The typical short-term response from a Soweto Electricity Crisis Committee activist is to embark upon technical training stressing insulation and effective pipe repair.

In short, the challenge for South Africans committed to a different society, economy and ecology is to humbly combine the limited gains that social movements have won so far (in many cases matched by regular defeats on economic terrain) with the soaring ambitions that are needed to match the scale of the systemic crisis and the current extent of social protest. There are ideological, strategic and material problems that South Africa's independent left has failed to overcome, including the division between autonomist and socialist currents, and the lack of mutual respect for various left traditions, including traditional Communism, Trotskyism, anarchism, syndicalism, Black Consciousness and feminism. A synthetic approach from the top down still appears impossible.

${ }^{12}$ Le Cordeur M. Eskom to Waive Soweto Users' Deb - On Condition // Fin24. May 25, 2016. URL: https://www.fin24.com/Debt/News/eskom-to-waive-sowetousers-debt-on-condition-20160525 (accessed: 07.02.2020). 
Single-issue and single-community struggles are important building blocks in the campaign to keep the fires of struggle and hope burning among the various sections of the working class. But the militancy of the community protesters must combine with that of organized and unorganized workers, students and unemployed youth, women fighting against rape and patriarchy. A conscious and planned build-up for an uprising can provide a basis for joint work and knitting together campaigns, with the aim of winning partial victories and strengthening bonds between the different sections of the working- class movement. An uprising will show a glimpse of what is possible when the working class movement is moving together in solidarity and action. It will liberate creative energy that will generate new ideas and methods of selforganisation and struggle. It will generate historical convulsions that can change the balance of forces, providing emerging movements with goals that can be generalized beyond the local and sectional. It will restore hope in the vision that things can be different, that a better world without oppression and exploitation is possible.

Received / Поступила в редакцию: 14.02.2020 Accepted / Принята к публикации: 17.03.2020

\section{References / Библиографический список}

Alternative Report on Africa. (2019). First Issue Terms of Reference for Country Studies. Unpublished paper. Dakar: ENDA, February.

Amin, S. (1990). Delinking. London: Zed Books.

Averbach, M. (1936). A Comment on Trotsky's Letter to South Africa. Revolutionary History, 4 (4), 131-133.

Bond, P. \& Galvin, M. (2019). Water, Food and Climate Commoning in South African Cities. In: Vivero-Pol, J.L. \& Ferrando, T. (Eds.). Routledge Handbook of Food as a Commons. London: Routledge. P. 231-248.

Bond, P. \& Malikane, C. (2019). Inequality Caused by Macro-Economic Policies during Overaccumulation Crisis. Development Southern Africa, 36 (6), 1-18. DOI: 10.1080/0376835X.2019.1701416

Bond, P. (2014). Elite Transition. London: Pluto Press.

Fine, B. \& Rustomjee, Z. (1996). The Political Economy of South Africa. Johannesburg: Wits University Press.

Fine, B. (2008). The Minerals-Energy Complex is Dead: Long Live the MEC? Amandla Colloquium. URL: https://eprints.soas.ac.uk/5617/1/MineralEnergyComplex.pdf (accessed: 02.02.2020).

Keynes, J.M. (1933). National Self-Sufficiency. The Yale Review, 22 (4), 755-769.

Kuhn, A. \& Wolpe, A.M. (Eds.). (1978). Feminism and Materialism. London: Routledge and Kegan Paul.

Magubane, B. (2001). The Social Construction of Race and Citizenship in South Africa. Working paper, UN Research Institute for Social Development, Geneva. URL: http://www.unrisd.org/unrisd/website/projects.nsf/ (httpAuxPages)/F1E2C56AA5442BD7C1256BDE002FBDC9?OpenDocument (accessed: 07.02.2020).

Marini, R.M. (1965). Brazilian Interdependence and Imperialist Integration. Monthly Review, 17 (7), 14-24.

Masondo, D. (2007). Capitalism and Racist forms of Political Domination. Africanus, 37 (2), 66-80.

Mbeki, T. (2004). Two Worlds: Two Economies. South African Labour Bulletin, 28 (2), 10-11.

Ngwane, T. (2019). Insurgent Democracy: Post-Apartheid South Africa's Freedom Fighters. Journal of Southern African Studies, 45 (1), 229-245.

Spaull, N. (2013). South Africa's Education Crisis. Centre for Development and Enterprise Working Paper, Johannesburg, October.

Wolpe, H. (1972). Capitalism and Cheap Labor Power in South Africa: From Segregation to Apartheid. Economy and Society, 1, 425-456.

About the authors: Ngwane Trevor - $\mathrm{PhD}$ in Sociology, Senior Lecturer in Sociology, University of Johannesburg, and President of the South African Sociological Association (e-mail: trevorngwane@gmail.com).

Bond Patrick - PhD in Economic Geography, Professor, School of Government, University of the Western Cape (e-mail: pbond@mail.ngo.za).

Сведения об авторах: Нгване Тревор - доктор социологии, старший преподаватель социологии Университета Йоханнесбурга, президент Южно-Африканской социологической ассоциации (е-mail: trevorngwane@gmail.com).

Бонд Патрик - доктор экономической географии, профессор, Школа управления, Университет Западной Капской провинции (e-mail: pbond@mail.ngo.za). 